\title{
What was fair in actuarial fairness?
}

\author{
Antonio J. Heras \\ Universidad Complutense de Madrid \& UNED, Spain
}

Pierre-Charles Pradier

Université Paris I Panthéon-Sorbonne, France

\section{David Teira}

UNED, Spain

\section{Forthcoming in History of the Human Sciences}

\begin{abstract}
In actuarial parlance, the price of an insurance policy is considered fair if customers bearing the same risks are charged the same price. The estimate of this fair amount hinges on the expected value obtained weighting the different claims by their probability. We claim that, historically, this concept of actuarial fairness originates in an Aristotelian principle of justice in exchange (equality in risk). We will examine how this principle was formalized in the $16^{\text {th }}$ century and shaped in life insurance during the next two hundred years, in two different interpretations. The Domatian account of actuarial fairness relies on subjective uncertainty: an agreement on risk is fair if both parties are equally ignorant about the chances of an uncertain event. The objectivist version grounds any agreement on an objective risk estimate drawn from a mortality table. We will show how the objectivist approach collapsed in the market for life annuities during the $18^{\text {th }}$ century, leaving open the question of why we still speak of actuarial fairness as if it were an objective expected value.
\end{abstract}




\section{Keywords}

actuarial fairness, annuity, history, life insurance, mathematical expectation

\section{Corresponding author:}

David Teira, UNED, Dpto. de Lógica, Historia y Filosofía de la ciencia, Senda del rey 7, 28040 Madrid, Spain.

Email: dteira@fsof.uned.es

\section{Actuarial fairness revisited}

Unlike in other fields of economics or finance, we find a normative concept at the core of actuarial sciences: we speak of the actuarial fair price of an insurance policy when customers bearing the same risks, pay the same amount. There is no separate theory of actuarial fairness though. For at least three centuries, practitioners and theoreticians alike have taken for granted the principle that equal risks should be charged the same price, using it as a benchmark for internal accountancy. Today, however, the pricing policies of insurance companies are putting this principle to test. On the one hand, new insurance regulation (e.g., the EU Solvency II Directive (2009/138/EC)) allows companies to manage their customers' risks as they see fit provided they meet strict controls of solvency. On the other hand, these risks can be now analysed with powerful statistical tools from the emerging world of Big Data. Whereas old actuaries classified customers according to broad risk profiles (for which there would be a single fair price), insurance companies are now refining their ability to predict the sum payable at the maturity of each of their policies, and more freedom to set their prices. Yet, rather than disappearing, the concept actuarial fairness seems to be in transition: e.g. in March 2011 the European 
Court of Justice took a ruling (C-236/09) prohibiting the use of a person's gender as a rating factor; the industry deemed it an 'unfair' decision (Landes, 2015).

We want to contribute to the ongoing redefinition of this concept of actuarial fairness with a historical outlook on its sources. ${ }^{1}$ In actuarial parlance, the expected value of an insurance policy provides its fair premium. For instance, the claim amounts of an insurance policy $\mathrm{X}$ can be 0 (with probability 0.81 ), 50 (with probability 0.18 ) and 100 (with probability 0.01 ). Its expected value is $10: \mathrm{E}(\mathrm{X})=0 \mathrm{x} 0.81+50 \mathrm{x} 0.18+100 \mathrm{x} 0.01=$ 10. Why is this expected value the best rendition of the same risks, same price principle? In the first half of this article, we will defend that the identification of actuarial fair prices with the expected value of insurance policies is just a historical contingency, not a matter of conceptual necessity. As we shall see in sections II-IV, in the $17^{\text {th }}$ century, early probability theorists used expected values to formalize an Aristotelian principle about the justice of contracts involving random events. We will dub this principle equality in risk: the distribution of costs and benefits in such contracts would only be fair if it was proportional to the risks each of the contracting parties took. Our modern concept of actuarial justice (same risks, same prices) was first articulated in the $17^{\text {th }}$ century when expected values were used to calculate the fair price of a particular insurance contract: life annuities ${ }^{2}$ (section V).

In section III we will present two different interpretations of this formalization of equality in risk that coexisted in the $17^{\text {th }}$ and $18^{\text {th }}$ centuries. On the one hand, we find a legal interpretation of the fairness of an aleatory contract we will call Domatian (after Jean Domat), in which the contracting parties calculate the expected value of the insurance policy on the basis of their agreed estimates of the chances of each outcome. This agreement on risks is fair to the extent that both parties are equally uncertain about the risks they are betting on. On the other hand, we find an objectivist account in which 
the agreement on an actuarial price was fair if the expected value of the contract was grounded on a mortality table capturing the objective risk of death.

In Sections IV and V we will illustrate how both versions of actuarial fairness were implemented to calculate the theoretically fair price of life annuities. For Jan De Witt, Domatian fair prices emerged from the agreement of the contracting parties without any separate estimation of the probabilities involved. For Edmund Halley or Nicholas Bernoulli, objectivist fair prices were based on an empirical estimate of the actual chances of death. In section VI we will contribute an analysis of how the proliferation of mortality tables led to the collapse of the objectivist account in the market for life annuities. Rather than leading to a converging set of fair actuarial prices, we will show how the different mortality estimates yielded instead conflicting prices which proto-actuaries rarely trusted for selling their policies.

Our inquiry is therefore a study in the history of the theoretical concept of actuarial fairness. We rely on already well-studied episodes in the development of modern probability and statistics, such as emergence of expected values and mortality tables. Our original contribution is to make explicit the different conceptions of justice underlying the discussion of fair actuarial prices throughout two centuries, together with a sort of empirical test for the objectivist account of fairness, the comparison between actuarial prices drawn from the available mortality tables until the early $19^{\text {th }}$ century. We focus thus on an abstract actuarial concept that reached our present evolving in parallel with a variety of pricing practices in insurance markets, without much influence on the latter. We hope our analysis will help in dispelling the illusion of objectivity that still pervades many contemporary debates on insurance prices. 


\section{The justice behind arithmetical means}

The first step in our argument is to show what concept of justice was formalized in the expected value version of actuarial justice. Historically, the same risks, same price principle stems from an Aristotelian tradition in which justice in exchange was appraised in terms of means. In the fifth book of the Nichomachean Ethics (EN 1131b25-1132b20), Aristotle addressed the problem of the justice of contracts through a mathematical analogy. Suppose that you have two parties with equal claims on a given good, but they have received unequal shares of it $(a, b)$ : the fair division of this good is the arithmetical mean of those unequal shares $(a+b) / 2$. Although Aristotle did not discuss in detail what would count as equal in actual exchanges, his intuition was enormously influential and it reached almost verbatim his medieval commentators (Fleischacker, 2004). E.g., for Aquinas a fair exchange is one in which the quantities traded do not deviate from the arithmetical mean of the total amount exchanged:

[I]f, at the start, both persons have 5, and one of them receives 1 out of the other's belongings, the one that is the receiver, will have 6 , and the other will be left with 4: and so there will be justice if both be brought back to the mean, 1 being taken from him that has 6 , and given to him that has 4 , for then both will have 5 which is the mean. (ST II-II, q61, a2). (Aquinas, 1947[1225-1274])

Within this Aristotelian background, the Schoolmen extensively discussed the fairness of the so-called aleatory contracts, in which the benefits and losses depended on an uncertain event ${ }^{3}$. Here emerged the principle of equality in risk ${ }^{4}$, of which we will present a particular version by Domingo de Soto (1494-1560). Soto was a Dominican theologian 
who systematized centuries of legal controversies among the Schoolmen in his monumental De Iustitia et Iure (Soto, 1967[1556]). In the $6^{\text {th }}$ and $7^{\text {th }}$ question of its $6^{\text {th }}$ book, Soto discussed the fair distribution of benefits and losses in partnership formed through an aleatory contract. His major claim is that an Aristotelian division (an arithmetical mean) would only be fair if the partners were taking equal risks in their contribution (be it capital or labor). If the risks they undertake are different, they should divide the total amount proportionally to those risks. ${ }^{5}$ This is what we call the equality in risk principle, which incorporates uncertainty into commutative justice.

Equality in risk allowed Soto to distinguish between insurance contracts and loans. In the latter, the owner of the money does not bear any risk at lending it: the recipient should return it, independently of the success of his venture, plus interest. Thereby the shadow of usury and, therefore, unfairness. In an insurance contract, both parties bear risk instead. The insured party will lose the insurance fee if no adversity occurs. The insuring party will cover the insured capital if there is an adversity. Hence, the premium is a compensation for covering this risk.

In the $17^{\text {th }}$ century, equality in risk was formalized in early probability theory, when Pascal and Huygens articulated the concept of mathematical expectation in order to analyze distribution problems in a particular kind of aleatory contracts: gambles (Daston, 1988: 49-110; Franklin, 2001: 306-16; Teira, 2006). In his Treatise on the arithmetical triangle (1665), Pascal addressed the so-called Problem of Points: how to distribute the bets in an interrupted gamble. According to Pascal, 'it should be strictly proportional to what they might rightfully expect from chance' (Pascal, 1963: 57). How could anyone quantify this fair expectation? In De ratiociniis in ludo aleae (1657), Huygens provided an algorithm. Let us assume a gamble in which two players may either earn $a$ if they win or $b$ if they lose: If I may expect either $a$ or $b$ and either could equally easily fall to my 
lot, then my expectation should be said to be worth $(a+b) / 2$ (Bernoulli, 2006: 133). Here we have an arithmetical mean, according to the Aristotelian principle of commutative justice. But the risk at which values are put is now implicitly quantified. Today we would read Huygens formula as a mathematical expectation: a probability weighted average, in which both outcomes $(a, b)$ are equiprobable.

This formalized equality in risk solved the Problem of Points: if the game is interrupted, each gambler should receive an amount equal to the expectation of the game. And this would be the fair price to pay for betting in such a gamble: for those who take the same risks, the price should be the same.

\section{Measuring risks through contracts, in theory and practice}

The expected value version of actuarial fairness originates thus in the Aristotelian equality in risk principle. Had Aristotle chosen a different analogy, we may have never appraised the fairness of a price in terms of arithmetical means. Historians have indeed shown how Huygens did not quantify risks directly through mathematical probabilities. Following a standard procedure in commercial mathematics (Sylla, 2003), Huygens studied gambling contracts and sought equivalences between them. To the extent that various contracts entailed the same risks, they would have the same expected value. An implicit quantification of probabilities arose therein.

Here is the argument Huygens used to articulate the concept of mathematical expectation. Imagine a simple game $\alpha$ (e.g., a series of coin tosses) with equal chances for the players to get outcomes $a$ or $b$ (where $a<b$ ). The two players start to play $\alpha$, but they are interrupted before the series of coin tosses reaches its end. Two new players want to replace them, each one of them paying an amount $x$ to gamble. The Problem of Points is about finding what $x$ should amount to, given $a$ and $b$, at the stage in which the game 
is interrupted. The two new players agree that the winner of this second gamble $\beta$ will earn $2 x$ and the loser will still get $a$. Following the usual procedure in commercial arithmetic, these two gambles ( $\alpha$ and $\beta$ ) will be equivalent if the winner in any of them gets the same prize, $b$. Hence, $2 x$ - $a$ should be equal to $b$. The amount $x$ that the two new players of the gamble $\beta$ should pay to replace the original players of gamble $\alpha$ is just equal to $(a+b) / 2$. This is the expected value of gamble $\beta$, and it will be the fair price of the (interrupted) gamble $\alpha$. The $1 / 2$ weight in the formula arises from 2 being the number of players betting in the gamble, not from a separate quantification of probability. ${ }^{6}$

Huygens provided thus the theoretical foundations of our current concept of actuarial fairness, formalizing the equality in risk principle. This is what we will call, from now on, the objectivist version of actuarial fair prices: the calculation of the premium hinges on the quantification of the different variables involved in the algorithm, assuming this quantification is unique.

Yet, almost nobody could estimate the actual equality in risk in an insurance contract at a time in which there was no separate quantification of probabilities. This was already true at the time of Soto, for whom there was no universal valuation of risks, and the contracting parties should reach an agreement on their own (Soto, 1967[1556]: 580). ${ }^{7}$ And this would be still the case in the $17^{\text {th }}$ and $18^{\text {th }}$ centuries. Our best guess as to how the fairness of an insurance contract was actually established is again legal theory. Among Pascal's closest friends, we find the jurist Jean Domat (1625-1696), author of a systematic treatise on The Civil Law in its Natural Order (1850[1689]), usually considered the first attempt at a rational systematization of French law. ${ }^{8}$

In the book, Domat discussed at various points the role of uncertainty in the fairness of an agreement. Consider, for instance, those covenants concerning an uncertain 
event, in which one of the contracting parties may, e.g., renounce all profit, and free himself from all loss. Domat claims that their justice is founded upon this:

$[O]$ ne party prefers a certainty, whether of profit or loss, to an uncertain expectation of events; and the other party, on the contrary, finds it his advantage to hope for a better condition. Thus, there is made up between them a sort of equality in their bargains, which renders their agreement just. (Domat, 1850[1689]: 186)

If the contracting parties have complementary expectations about the outcome, the agreement is fair. Their expectation depends, of course, on their subjective estimation of their chances of suffering from a certain adversity. For Domat, this subjective estimate provides good enough grounds for a fair agreement inasmuch as the contracting parties are equally uncertain about the outcome. E.g. imagine a 'universal partnership' in which all the partners contribute a given amount of money so that if any of them has a daughter, they will be able to fund the dowry from the 'joint stock' (ibid.: 354-5). According to Domat, this is fair because all the partners were 'under the same uncertainty of the event [having a daughter], and with the same right, having rendered their condition equal, it made also their agreement just'. ${ }^{9}$

Here is a second version of actuarial fairness in which the equality of risk is assessed in in terms of equal ignorance: nobody could exploit the other party's ignorance for his own benefit. Let us call it the Domatian interpretation of equality in risk. Unlike the objectivist version, it does not presuppose an independent procedure for risk quantification (arising from the symmetries in the contract, as in Huygens, or whatever other source). In the Domatian approach, the contracting parties may come up with any risk figures they are willing to agree on, and the agreement will be fair (as the subsequent 
price), provided none of them is hiding information that should be reflected in such figures. As we are going to see in the next two sections, both accounts in the interpretation of actuarial fairness coexisted in the transition to the $18^{\text {th }}$ century.

\section{Actuarial fairness, the Domatian version}

Let us know see how the Domatian version of actuarial fairness is at work in Jan de Witt's (1625-1672) piece on the 'Value of life annuities in proportion to redeemable annuities' (De Witt, 1995[1671]), De Witt presided over the United Provinces of Holland and the paper was written as a report addressed to the States-General of Holland. The country was considering the issuance of life annuities at a fixed price (i.e. regardless of age), which De Witt wanted to compare to the price of perpetual annuities In exchange for this price, a life annuity would provide a series of equal payments for the remainder of the buyer's lifetime. Throughout centuries different institutions had been financing themselves with the sale of annuities, but De Witt's is considered the first author to compute the value of a life annuity as the sum of expected discounted future payments (Daston, 1988: 27-8; Hald, 1990: 123-31; Turnbull, 2016: 11-13).

In this calculation De Witt operated in the normative framework presented above, exploiting the analogy between life annuities and gambling contracts. On the one hand, the prize of the gamble corresponded to the income the annuity buyer may obtain depending on the duration of his life. On the other hand, the chances of each outcome in the gamble correspond to the chances of the buyer dying at any particular point in time. Hence, using Huygens' approach, De Witt could calculate the expected value $\left(a_{x}\right)$ of a life annuity for a person of age $x$ as follows. In our current notation (Hald, 1990: 128), the formula for his algorithm would be: 


$$
a_{x}=\frac{1}{l_{x}} \sum_{t=1}^{w-x-1} a_{t} d_{x+t}
$$

The outcomes of the gamble are $a_{\hat{t}}$, where $a_{\hat{t}}$ is the current value of an annuity paid every six months (at a $4 \%$ annual interest rate) over $t$ half-years. The number of deaths in each period $x+t$ is $d_{\mathrm{x}+\mathrm{t}}$. The sum of the number of deaths from age $x$ (in half-years) onwards is $l_{x}=d_{x}+d_{x+1}+\ldots+d_{w-1}$, where $w$ is the maximum number of half-years in which the annuity will be paid. As (Hald, 1990: 128) observes, $d_{x+t} / l_{x}$ is a probability distribution. But this is not how De Witt estimated the chances of dying. He first divides a person's life in four intervals: $(3,53),(53,63),(63,73)$ and $(73,80) .{ }^{10}$ The chances of anyone dying in any of these four intervals are estimated as follows:

[T]aking for example two persons of equal constitution, one aged 40 years, and the other 58 years, if these two persons made such a contract, that in case the person of 58 years should happen to die in less than 6 months, the one aged 40 were to inherit a sum of 2000 florins from the property of the defunct; but that if, on the other hand, the person aged 40 years should die in less than 6 months, the other aged 58 years were to have 3000 florins from the property of the deceased; such a contract cannot be considered disadvantageous for the person who would have the 3000 florins, if the event were favourable to him, and who, in the contrary event, would only lose 2000 florins. (De Witt, 1995[1671]: 2)

The chances of anyone dying in these two intervals are inferred from the fairness of the contract: for De Witt, the proportion between the chances of dying of a person whose age is the range (53-63) and the chances of one in the (3-53) range are 3 to 2, because if the older person dies, the amount to be paid is only $2 / 3$ of the amount due if the younger one 
dies. This is the Domatian, rather than the objectivist version, of actuarial fairness: there is no independent quantification of risks; the contracting parties implicitly agree on their respective chances if they do not consider the payout 'disadvantageous'.

In buying a life annuity at a price calculated according with De Witt's formula, the contracting parties implicitly agree on a given proportionality of chances for each age range: taking $(3,53)$ as the baseline, the proportion will be $2 / 3$ for $(53-63), 1 / 2$ for $(63,73)$ and $1 / 3$ for $(73,80)$. De Witt's formula will then comply with the equality in risk principle if the buyers of age within a given interval take themselves to have the same chances of dying, and the same given proportion regarding the buyers in the other intervals. In accepting this distribution of chances, they acknowledge that they all were 'under the same uncertainty of the event': otherwise they would exploit someone else's ignorance. ${ }^{11}$

\section{Actuarial fairness, the objectivist version}

Let us now see how the objectivist account of actuarial fairness emerged at the turn of the $18^{\text {th }}$ century thanks to mortality tables. These latter would be the independent source for the quantification of the risk of death, setting apart the two accounts we will examine (Halley and Bernoulli) from De Witt's Domatian approach.

In 1693, Edmund Halley published in the Philosophical Transactions of the Royal Society, his 'estimate of the degrees of mortality of mankind', based on the records of the city of Breslaw (Daston, 1988: 125-38; Hald, 1990: 131-41; Turnbull, 2016: 13-16). For Halley, 'the price of insurance upon lives ought to be regulated' (Halley, 1693: 602) on these mortality tables, since they provided an empirical estimate of the chances of people dying at a certain age. Whereas De Witt had estimated these chances on the basis of a contract, Halley now argues on death frequencies as follows: if we want to ensure the lives of two men of 20 and 50: 'It being 100 to 1 that a Man of 20 dies not in a year, and 
but 38 to 1 for a Man of 50 Years of Age' (ibid.). For Halley, 'it is plain that the Purchaser ought to pay for only such a part of the value of the Annuity, as he has Chances that he is living' (ibid.). I.e., what is plain for Halley is the equality in risk principle: same risks, same price. Except that now the risks are inferred from statistical records. Nonetheless, adopting Breslaw's mortality table as the source of every risk estimate is objectionable, as Halley himself acknowledges: 'it may be objected, that the different Salubrity of places does hinder this proposal from being universal; nor can it be denied' (ibid.: 619). For Halley, this is an empirical matter, subject to further investigation.

Nicolas Bernoulli concurred in this point with Halley. In 1711, he published a summary of his doctoral dissertation on the use of the Ars conjectandi in Law (Bernoulli, 1992[1711]; Daston, 1988: 136-7; Hald, 1990: 110-15). A couple of years later, Nicolas published his uncle's unfinished Ars Conjectandi, a landmark establishing the foundations of modern probability theory. The framework of Nicolas' dissertation is still normative, though. In chapter IV, Nicolas discusses the legal foundations of the pricing of life annuities. In a Domatian spirit, he claims that the only foundation for these prices is the reason of the contracting parties (ratione contrahentium), since it should be fixed at the time of their agreement (and not when the outcome on which the contract hinges happens). Yet, Bernoulli shifts to the objectivist account of fairness:

It is clear that the price cannot be established without taking the buyer's age and health into consideration, of which we should have the best knowledge in order to set the price of a life annuity. The same annuity cannot be sold indifferently to men of all ages. (Bernoulli, 1992[1711]: 62) [Our translation] 
Drawing on a summary of John Graunt's 1662 mortality table, Nicolas proceeds to estimate the length of the human life. However, he observes that some further data from an unidentified Swiss city disagree with his estimates. These should remain hypothetical, he observes, inviting, like Halley, further research on the topic.

Hence, unlike in De Witt's Domatian approach, the mortality tables set an objective assessment of risks upon which the fair price of an annuity could be calculated. Historians of probability have indeed discussed Halley's and Bernoulli's contributions mostly in terms of their assumptions about the regularity of death: whether there was an underlying stability in mortality statistics that they could grasp with their data (Daston, 1988: 125-38; Hacking, 1975: 119-22). This was a powerful ideal that, as we will see next, inspired the construction of many other mortality tables during the following centuries. ${ }^{12}$

Yet, historians of probability have so far neglected a second problem that any objectivist account of actuarial fairness was bound to encounter. This is what philosophers of probability call today the reference class problem (Hájek, 2007): assigning a probability to the risk of death of a particular individual depends on the relevant risk factors to classify an individual. The probability will change depending on whether the actuary takes into account tables which just consider, e.g., 'age and health', or also 'the different Salubrity of places', or whatever other factors impinge on mortality. If the actuary could grasp in full the laws of mortality covering all these factors, there might be just one mortality table, and the calculation of actuarial fair prices would be as objective as it could possibly be. Yet, as we are going to see in the next section, actuaries only have access to partial mortality tables often with diverging probability estimates. Under these circumstances, could they estimate anything like an actuarial fair price on an objective basis? 


\section{Actuarial justice in the actual markets}

The best way to grasp the differences between the objectivist and the Domatian versions of actuarial justices is to see them in conflict. Eve Rosenhaft provides a splendid illustration in her analysis of the collapse of a German widows' pensions fund in the late $18^{\text {th }}$ century (Rosenhaft, 2010). Established in Hannover in 1767, the Calenbergische Witwenversorgungs-Gesellschaft (the Calenberg, from now on), recruited in about a decade more than 5000 married couples from all over Europe. The Calenberg had been designed using the Süssmilch 1741 mortality table (Süssmilch, 1761) and contributions took age into account. It was therefore one of the first actuarially based funds, comparable to the British Equitable Society (Ogborn, 1962). Yet, early after its establishment, qualified experts like George Christian von Oeder and Johann Nicolaus Tetens criticized the actuarial foundations of the Calenberg, questioning its long-term solvency. In the early 1780 s, a large group of subscribers refused to pay their contribution and recruited, among others, Tetens to advise them in a negotiation with the Calenberg administrators, who recruited a committee of lawyers from the University of Leipzig to adjudicate the case.

The protesters argued that there was a 'fundamental error' in the design of the fund (Rosenhaft, 2010: 29), because, in Tetens' words, the 'general calculation of the business' had not been made by 'algebrists', but 'mere adders-up' (ibid.: 32). Therefore, the subscribers had been 'cheated'. The widows already receiving pensions from the Calenberg replied that the fund was based on an aleatory contract, in which the subscribers had 'knowingly [entered into] an insecure transaction in which he could win and [i.e., or] lose' (ibid.: 34). The Leipzig jurist adjudicated that indeed the Calenberg depended 'on the length of human life, and so on a completely uncertain outcome' (ibid.). 
In our terms, the protesters were invoking the objectivist version of actuarial justice. Given a mortality table, there is only one fair amount for the fund premium. The Leipzig jurists countered along Domatian lines: ultimately the fairness of the contract depended on the shared uncertainty about the husbands' death, and mortality tables did not make it less uncertain for any of the fund stakeholders. ${ }^{13}$ The purported objectivity of actuarial prices might have been more credible in a world with just one mortality table, i.e., a single life expectancy estimate. As Struyck declared in 1740: 'I think if unbiased people were taking data on annuities from other accounts in other countries, considering all the people who bought insurance around the same time, dividing them into classes and noting the number of years during which they drew their pensions, the same way I did above, they would arrive at a nearly identical result' (Our translation) (Struyck, 1912[1740]).

Yet, as table 1 below shows, in between 1662 and 1769, a growing number of mortality tables for different European populations were published, exhibiting striking differences in their mortality estimates (figure 1), not only due to the increasing longevity of Europeans.

Although Halley's approach set the standard for most of the subsequent tables, the methodology remained in constant development for two centuries. In the 1720 s, De Moivre and de Graaf provided some analytical approximations for Graunt's and Halley's tables. Simpson (1742) addressed the (so far, implicit) problem of assuming a constant population in constructing a life table from mortality data. In the following 100 years, the subsequent tables used larger samples and more sophisticated methodologies (Murray, 2016).

However, the discrepancies between all these mortality tables are not just a matter of sampling and methodology. The tables were also constructed with different goals, 
exhibiting a clear awareness that not all of them were fit for insurance valuation. For instance, Graunt, Buffon or Moheau were addressing issues in demography: in Graunt's own words, 'it may now be asked, to what purpose tends all this laborious bustling and groping to know, 1. The number of people? 2. The number of male and female? 3 . How many married and single?' (Birch, 1759: 35). Some other tables cared instead for protoepidemiological questions, namely the increase in life expectancy resulting from inoculation of infants (Bernoulli, 1982[1765]; Lambert, 1772). Some of the tables were constructed instead for actuarial purposes, as was the case of De Witt's.

According to (Hup, 2011), between 1662 and 1713 in the Low Countries, only $20 \%$ of the life annuities actually sold provided insurance for adults against future poverty; the remaining $80 \%$ were placed on healthy children with a view to maximizing the expected return of the annuity. ${ }^{14}$ With this gamble in sight, De Witt had argued in 1671 that an $8 \%$ price for life annuities was too generous, suggesting instead an amount closer to $6.67 \%$ (16 years' purchase), computed to match the highest life expectancy among the annuitants. This was reflected on his mortality table: if we take Halley's table as a purely descriptive benchmark, we see De Witt's underestimation of the mortality of the first age rank (3-18) raises the value of annuities placed on young lives only.

The consequences for the objectivist account of actuarial fair prices are straightforward. As table 2 shows, in our array of mortality tables, life expectancies at 6 ranged from 19 to 48 years; at 20 from 19 to 40; and at 50 from 10 to 20 . Table 3 displays the corresponding price of life annuities: although the variance is less, one can still find an $80 \%$ difference between the lower and higher price at $6,60 \%$ at $20,50 \%$ at 50 , etc. We concur with (Clark, 1999: 114-54) about the lack of solid reasons for proto-actuaries to use mortality tables. They were reasonably skeptical about the accuracy of the data to capture the risk factors of their actual pool of customers and, trusting their own 
experience, they often succeeded at organizing viable financial schemes. A powerful rationale behind their skepticism is the reference class problem: when there is more than one probability estimate for the life expectancy of a given individual, which one will be the fair choice?

\section{Concluding remarks: The aftermath}

In our view, the $18^{\text {th }}$ century saw the collapse of the objectivist version of actuarial fairness: the proliferation of mortality tables dispelled any illusion of having an algorithm to calculate one single fair price for every life annuity. This conclusion opens, at least, two further questions. On the one hand, why did the concept of actuarial fairness survive, apparently untouched, until our days? On the other hand, why did not the Domatian interpretation come to prevail over the objectivist account? We offer two conjectures, by way of conclusion.

As to the survival of the objectivist account, our simple conjecture is that this concept of actuarial fairness was revived as a marketing tool in the United Kingdom and the United States at a point in which companies were converging on unified mortality tables. ${ }^{15}$ This convergence made the idea of the single fair price credible. In the market for annuities this happened relatively early. In 1829, the British Treasury issued very large amounts of life annuities in order to repay government debt, choosing John Finlaison's mortality tables to price them. Finlaison had earned himself an appointment as Actuary of the National Debt Office, showing the money his estimates could save to the Treasury. The crucial difference was not in Finlaison's method, ${ }^{16}$ but in the situation: in times of peace, there was no urgency to squeeze the money out of the public by offering high returns, in competition with private insurance companies. The British Treasury could now offer lower returns, grounded on Finlaison's tables, but with fewer prospects of 
bankruptcy than any private seller. Even if there were competing mortality tables, the State set a risk benchmark in terms of solvency: Finlaison's tables signalled all the risk a State was willing to cover for.

Yet, Finlaison's table never became the benchmark for other life insurance markets in the UK, since the British administration never sold anything other than annuities. Throughout the $19^{\text {th }}$ century British and American insurance companies (Murphy, 2010) chose one or another life table depending on whether they wanted to reduce premiums or pay dividends to their shareholders. According to Alborn (2009: 103), it took until the 1880 s till British companies adopted tables elaborated by the Institute of Actuaries and the Faculty of Actuaries, even if these tables represented just the life expectancy of one particular type of customer (certain types of healthy white males). Everybody else was simply charged in excess for their risks (ibid.: 116-21). In other words, even if there was a single mortality table, this table did not properly represent the risks of the entire customers' pool, just a majority of them (in the best possible scenario). The same risks, same price principle does not apply here. Following (Bouk, 2015: 4), our best conjecture is that, in a packed marketplace, equity became a marketing tool: 'it allowed life insurers to attract sound lives with insurance offered at a lower price'.

Then, if it had some marketing value, why did the Domatian interpretation of actuarial fairness not compete any further with the objectivist account, despite its flaws? Again, this is an open research question and we can only speculate. The Domatian view of aleatory contracts was incorporated into the Napoleonic Code (arts. 1964-1983) and exerted through it a significant influence on Continental law. In life annuities, for instance, for the uncertainty to be genuine, death should not be predictable 20 days in advance. ${ }^{17}$ Otherwise, there would not be enough of an alea for such a contract to qualify as aleatory (Aubry and Rau, 1871: 584). Yet, life insurance thrived under the Common 
Law in Anglo-saxon countries, where, according to Alborn (2009: 221), companies rarely tried to penalize events after the policy was issued. After the Gambling Act of 1774, the major legal issue in the Anglo-saxon world seems to have been about the concept of insurable interest (Merkin, 1980). The Domatian view of justice may have had a life of its own, outside life insurance, in Continental law still to be explored.

The history of how the concept of actuarial fairness evolved through the $19^{\text {th }}$ and $20^{\text {th }}$ century to our days is yet to be written. Yet, we may conclude that when actuaries currently speak of fair insurance prices in terms of expected values, they just follow a centenary tradition without real consideration of what was fair about them. On the one hand, as we have just shown, the formalized version of the equality in risk principle for life insurance went hand in hand with an objectivist account of risks that never fully materialized. On the other hand, the same risks, same price principle originates on an Aristotelian intuition about justice in exchange. This intuition hinges on a mathematical analogy, by which arithmetical means (with or without risk weights) capture the equality between the exchanging parties. After more than a century of neoclassical theorizing about markets, it is difficult to sustain the idea that prices reflect anything objective about the goods exchanged, other than an agreement between buyers and sellers. In this regard, the equality in risk principle has lost its original normative force, precisely because no sort of equality is a pre-requisite for fair exchanges. Hence, it would not hurt to consider alternative principles of justice if we are to rethink actuarial fairness today (Meyers and Van Hoyweghen, 2018). 


\section{Funding information:}

David Teira received a research grant from the Spanish Ministerio de Economía y Ciencia (FFI2014-57258-P).

\section{Acknowledgements}

We thank the audience at the workshop Performativity and the Governance of Actuarial Models (EHESS, 2018) for their comments on our presentation, plus the suggestions of several reviewers and the editorial care of Chris Renwick, our handling editor at this journal. The Library of Fundación Mapfre (Madrid) kindly provided some precious references.

\section{References}

Alborn, T. L. (2009) Regulated Lives: Life Insurance and British Society, 1800-1914. Toronto: University of Toronto Press.

Aquinas, T. (1947[1225-1274]) The Summa Theologica: Complete Edition, trans. Fathers of the English Dominican Province. N. York: Benzinger Bros.

*Aubry, C. and Rau, C. (1871) Cours de droit civil français, t. 4. [Course of French Civil Law]. Paris: Imprimerie et librairie générale de jurisprudence.

Bellhouse, D. R. (2011) 'A New Look at Halley's Life Table', Journal of the Royal Statistical Society: Series A (Statistics in Society) 174(3): 823-32.

*Bernoulli, D. (1982[1765]) 'Essai d'une nouvelle analyse de la mortalité causée par la petite vérole, et des avantages de l'inoculation pour la prévenir' [An Attempt at a New Analysis of the Mortality Caused by Smallpox and of the Advantages of Inoculation to Prevent it], in L.P. Bouckaert et al. (eds) Die Werke von Daniel Bernoulli [The Works of Daniel Bernoulli], Vol. 2. Basel: Birkhäuser, pp. 1-45. 
Bernoulli, J. (2006) The Art of Conjecturing, Together with Letter to a Friend on Sets in Court Tennis, ed. E. D. Sylla. Baltimore: Johns Hopkins University Press.

*Bernoulli, N. (1992[1711]) L'usage de l'art de conjecturer en droit [The use of the Art of Conjecturing in Law], ed. N. Meusnier. Paris: Seminaire Histoire du calcul des probabilités et de la statistique.

Birch, T. (1759) A Collection of the Yearly Bills of Mortality, From 1657 to 1758 Inclusive. London: A. Millar.

Bouk, D. B. (2015) How Our Days Became Numbered: Risk and the Rise of the Statistical Individual. Chicago: University of Chicago Press.

*Buffon, G. L. (1749) Histoire naturelle générale et particulière [Natural History, General and Particular], Vol. 2. Paris: Imprimerie royale.

Ceccarelli, G. (2001) 'Risky Business: Theological and Canonical Thought on Insurance from the Thirteenth to the Seventeenth Century', Journal of Medieval and Early Modern Studies 31(3): 607-58.

Clark, G. W. (1999) Betting on Lives: The Culture of Life Insurance in England, 16951775. Manchester: Manchester University Press.

*Coumet, E. (1970) 'La théorie du hasard est-elle née par hasard?' [Was the Theory of Chance Born By Chance?], Annales. Économies, Sociétés, Civilisations 25 (3): 574-98.

Daston, L. (1988) Classical Probability in the Enlightenment. Princeton, NJ: Princeton University Press.

De Moivre, A. (1725) Annuities upon Lives. London: Chelsea Publishing Company.

De Witt, J. (1995[1671]) 'Value of Life Annuities in Proportion to Redeemable Annuities', in S. Haberman and T. A. Sibbett (eds) History of Actuarial Science. London: William Pickering, pp. 144-64. 
*Demonferrand, F. (1835) Essai sur les lois de la population et de la mortalité en France [Essay on the Laws of Population and Mortality and France]. S.l.: s.n.

*Deparcieux, A. (2003[1746]) Essai sur les probabilites de la duree de la vie humaine [Essay on the Probabilities of the Human Lifespan], eds. C. Behar et al. Paris: Institut national d'etudes demographiques.

Dodson, J. (1756) First Lectures on Insurance. Manuscript, Institute and Faculty of Actuaries.

Domat, J. (1850[1689]) The Civil Law in its Natural Order, trans. L. S. Cushing. Boston: Charles C. Little and James Brown.

*Duvillard De Durand, J. H. T. E. É. (1806) Analyse et Tableaux de l'influence de la petite vérole sur la mortalité à chaque age [Analysis and Tables of the Influence of Smallpox on Mortality at each Age]. Paris: Imprimerie Impériale.

*Euler, L. (1760) 'Recherches générales sur la mortalité et la multiplication du genre humain' [General Investigations on the Mortality and the Multiplication of the Human Race], Mémoires de l'académie des sciences de Berlin 16: 144-64.

Finlaison, J. (1829) Report of John Finlaison, Actuary of the National Debt, on the Evidence and Elementary Facts on which the Tables of Life Annuities are Founded. London: H. M. Stationery Office.

Fleischacker, S. (2004) A Short History of Distributive Justice. Cambridge, MA: Harvard University Press.

Franklin, J. (2001) The Science of Conjecture: Evidence and Probability before Pascal. Baltimore: Johns Hopkins University Press.

Gordley, J. (1993) The Philosophical Origins of Modern Contract Doctrine: Oxford: Clarendon Press. 
Hacking, I. (1975) The Emergence of Probability: A Philosophical Study of Early Ideas About Probability, Induction and Statistical Inference. London: Cambridge University Press.

Hájek, A. (2007) 'The Reference Class Problem Is Your Problem Too', Synthese 156(3): 563-85.

Hald, A. (1990) A History of Probability and Statistics and their Applications before 1750. New York: Wiley.

Halley, E. (1693) 'An Estimate of the Degrees of the Mortality of Mankind', Philosophical Transactions of the Royal Society 1(17): 596-610.

Hup, M. (2011) 'Life Annuities as a Resource of Public Finance in Holland, 1648-1713. Demand- or supply-driven?', BSc Thesis, Universiteit Utrecht.

*Iglesias, A. (2009) 'Filosofía y derecho en Jean Domat' [Philosophy and Law in Jean Domat], PhD Thesis, Universidad Carlos III de Madrid.

*Kersseboom, W. (1738) Verhandeling tot een proeve om te weeten de probable menigte des volks in de provintie van Hollandt en Westvrieslandt [Treatise on an Experiment to Know the Probable Mass of Population in the Province of Hollandt and Westfrieslandt]. S.1.: s.n.

*Kersseboom, W. (1742) Eerste verhandeling tot een proeve om te weeten de probable menigte des volks in de provintie van Hollandt en Westvrieslandt [First Treatise on an Experiment to Know the Probable Mass of Population in the Province of Hollandt and Westfrieslandt]. S.l.: Jan vanden Bergh.

*Kritter, J. A. (1780) 'Untersuchung des Unterscheides der Sterblichkeit der Männer und der Frauen von gleichen Alter' [Investigation of the Difference of Mortality of Men and Women of Equal Age], Göttingisches Magazin der Wissenschaften und Litteratur 2: 229-58. 
*Lambert, J. H. (1772) Beyträge zum Gebrauche der Mathematik und deren Anwendung [Contribution to the Usage of Mathematics and its Application]. S. 1.: Verlag des Buchladens der Realschule.

Landes, X. (2015) 'How Fair Is Actuarial Fairness?', Journal of Business Ethics 128(3): 519-33.

*Le Bras, H. (1998) Le démon des origines: démographie et extrême droite [The Devil of Origins: Demography and Extreme Right]. La Tour d'Aigues: L'Aube.

Merkin, R. (1980) 'Gambling by Insurance - A Study of the Life Assurance Act 1774', Anglo-American Law Review 9(3): 331-63.

*Messance, L. (1766) Nouvelles recherches sur la population de la France, avec des remarques importantes sur divers objets d'administration [New Research on the Population of France, with Important Remarks on Various Objects of Administration]. Paris: Durand.

Meyers, G. and Van Hoyweghen, I. (2018) 'Enacting Actuarial Fairness in Insurance: From Fair Discrimination to Behaviour-based Fairness', Science as Culture 27(4): 413-38.

Milne, J. (1815) A Treatise on the Valuation of Annuities and Assurances on Lives and Survivorships. S. 1.: Longman, Hurst, Rees, Orme, and Brown.

*Moheau, J. B. (1778) Recherches et considérations sur la population de la France [Research and Considerations on the Population of France]. Paris: Moutard.

Monsalve, F. (2014) 'Scholastic Just Price Versus Current Market Price: Is it Merely a Matter of Labelling?', The European Journal of the History of Economic Thought 21(1): 4-20.

Morris, C. (1759) Observations on the Past Growth and Present State of the City of London. London: A. Millar. 
Murphy, S. A. (2010) Investing in Life: Insurance in Antebellum America. Baltimore: Johns Hopkins University Press.

Murray, L. L. (2016) 'Data Smoothing Techniques: Historical and Modern', Ph.D. Thesis, University of Western Ontario.

Ogborn, M. E. (1962) Equitable Assurances. The Story of Life Assurance in the Experience of the Equitable Life Assurance Society, 1762-1962. London: George Allen \& Unwin.

*Pascal, B. (1963) Euvres complètes [Complete Works], ed. L. Lafuma. Paris: Seuil.

Pradier, P. C. (2016) 'The Debt of the Hôtel-Dieu de Paris from 1660 to 1690: A Testbed for Sovereign Default', Working Paper, Centre d'économie de la Sorbonne. Paris.

Price, R. (1773) Observations on Reversionary Payments. S. 1.: Printed for T. Cadell.

*Rohrbasser, J. M. and Véron, J. (1999) 'Les frères Huygens et le "calcul des aages": l'argument du pari équitable' [The Huygens Brothers and the 'Calcul des Ages': The Argument of the 'Pari Equitable'], Population 54(6): 993-1011.

Rosenhaft, E. (2010) 'How to Tame Chance: Evolving Languages of Risk, Trust, and Expertise in Eighteenth-century German Proto-insurances', in G. Clark et al. (eds) The Appeal of Insurance. Toronto: University of Toronto Press, pp. 16-42.

*Santarem, P. d. (1971[1552]) Tractatus de assecurationibus et sponsionibus [The Treatise on Insurance]. Lisboa: Grémio dos Seguradores.

Simpson, T. (1742) The Doctrine of Annuities and Reversions. S.1.: Printed for J. Nourse. Smart, J. (1738) 'A Table Showing the Probabilities of Life', in S. n., The Bills of Mortality for the City of London. London: Guildhall Library.

*Soto, D. d. (1967[1556]) De iustitia et iure libri decem. De la justicia y del derecho: en diez libros [On Justice and Law in Ten Books], trans. V. Carro. Madrid: Instituto de Estudios Políticos. 
Stone, D. A. (1993) 'The Struggle for the Soul of Health Insurance', Journal of Health Politics, Policy and Law 18(2): 287-317.

*Struyck, N. (1912) Les cuvres de Nicolas Struyck (1687-1769) qui se rapportent au calcul des chances, à la statistique générale, à la statistique des décès et aux rentes viagères [The Works of Nicolas Struyck (1687-1769) regarding the Calculation of Chances, General Statistics, Death Statistics and Life Annuities], ed. J. A. Vollraf. Amsterdam: Martinus Nijhoff.

*Süssmilch, J. P. (1761) Die göttliche Ordnung in den Veränderungen des menschlichen Geschlechts [The Divine Order in the Changes in the Human Race]. Berlin: Verlag des Buchladens der Realschule.

Sylla, E. D. (2003) 'Business Ethics, Commercial Mathematics, and the Origins of Mathematical Probability', History of Political Economy 35(5): 309-37.

Teira, D. (2006) 'On the Normative Dimension of the St. Petersburg Paradox', Studies in History and Philosophy of Science Part A 37(2): 210-23.

Turnbull, C. (2016) A History of British Actuarial Thought. New York, NY: Springer Berlin Heidelberg.

*van Ham, D. (2005) 'De tafel van afsterving van Johannes Hudde' [Johannes Hudde's table of deaths], De Actuaris (Juli): 31-3.

Wargentin, P. (1995) 'Mortality in Sweden According to the "Tabell-Verket"', in S. Haberman and T. Sibbett (eds) History of Actuarial Science, Vol. 2. London: William Pickering, pp. 11-38.

\section{Notes}


1. We will discuss the concept of actuarial fairness focusing on its narrow use among actuaries, mostly concerned about pricing insurance policies through mathematical expectations. There are broader conceptions of actuarial fairness we will not discuss here: e.g., the solidarity principle advocated in Stone (1993).

2. In the $17^{\text {th }}$ and $18^{\text {th }}$ centuries, annuities offered a series of annual payments upon a named person's death (the nominee) in exchange for either a lump sum or a series of regular payments. Although annuities are not technically a form of life insurance, during the period we will examine they were considered as such: see Clark (1999: 95-102).

3. The connection between aleatory contracts and insurance has been explored in Ceccarelli (2001). Following Coumet's seminal paper, the role of aleatory contracts in the formation of the modern concept of probability has been extensively discussed namely by Daston (1988: 15-33), and Franklin (2001: 25888). The discussion of the moral dimension of these contracts for late Medieval and early Modern catholic thinkers usually hinges on the legitimacy of usury (taking interest on loans). Here we focus instead on how to quantify the fair amount of gains to be received from such contracts, assuming they are licit. Unlike Daston (1988: 19), who treats equity, in purely legal terms, we highlight the moral foundations of aleatory contracts placing them in the framework of Aristotelian commutative justice. For earlier formulations of equality in risk in the $14^{\text {th }}$ century, see Alexander Lombard and Baldus (Franklin, 2001: 271-2). Already in the $17^{\text {th }}$ century we find it in Lessius or Juan de Lugo (ibid.: 287-8).

4. Equality in risk is just a probabilistic twist on what legal scholars have dubbed equality in exchange (Gordley, 1993: 94-102). Historically, there was no agreement in the Aristotelian tradition as to how to quantify the just price of a fair 
exchange -beyond some general rules of thumb. There are equally conflicting views among contemporary scholars about the correct understanding of commutative justice, whether just prices are just the production costs or the actual market prices, for instance Monsalve (2014).

5. Ceccarelli (2001: 610-12) discusses Soto's views on the fairness of insurance contracts. Teira (2006: 214-16) examines the influence of this view on the development of early probability theory.

6. This is now the standard interpretation of the birth of the concept of mathematical expectation from the Problem of Points -see, e.g. Daston (1988). It is incorporated as such in recent histories of actuarial thought: e.g. Turnbull (2016: 5-8).

7. It is interesting to notice the contrast between Soto's abstract discussion of fair insurance prices with the legal analysis of Pedro de Santarem in 1552 (Santarem, 1971[1552]), much closer to real actuarial practices. For Santarem, the just price shouldn't deviate more than one half from the premium 'assurers normally receive for the acceptance of risk' (Book V, Section 6). The token premium of Santarem for maritime insurance is an $8 \%$ of the cargo (e.g., B. III, s.25; s. 34).

8. Domat has not been studied as much as his influence would deserve. The most systematic (recent) monograph is Iglesias (2009). Coumet (1970) pioneering paper was the first to alert of the relevance of Domat's ideas on aleatory contracts to understand the birth of probability theory.

9. Following Gordley (1993: 109-11), we should notice that appealing to the consent of the contracting parties implies no departure from the Aristotelian tradition: 'the parties to an exchange could only have intended that the contract preserved equality' [in risk, in this case] (110). As Gordley correctly observes (ibid.), this cannot be further from our own understanding of contractual obligations, in which 
the will of the parties is set apart from the justice of the agreement. We simply do not share anymore the metaphysics of essences underlying this Aristotelian conception of equality, by which there could only be one equal (fair) exchange.

10. The analytical assumption of a constant probability of death in an age range was widely shared at the time: see Clark (1999: 122).

11. We disagree here with the objection of circularity raised against De Witt in Daston (1988: 28-33). According to Daston, De Witt could avoid the definition of either equiprobability or probability just because all his proofs dealt with equal contracts among partners in completely symmetric situations. The number of partners was always equal to the number of outcomes and the number of chances. Outside this sort of equal contracts, there would be indeed no independent definition of probability and therefore no assessment of the fairness of contracts involving unequal risks. Nonetheless, for De Witt the equality in risk (of dying) was structured according to four entirely conventional age ranks (Daston, 1988: 125), for which we don't think any probabilistic justification was necessary. As we have argued, customers were free to accept or reject them on whatever basis they saw fit and this is precisely the source of the dilemma we appreciate in the definition of actuarial fairness. Neither the issuer nor the buyer of the annuity negotiated the exchange in terms of an independent/objective definition of the actual chances involved, but rather second-guessing the accuracy of each other's estimates of the relevant risks.

12. A reviewer objects that the difference between the Domatian and the objectivist approach 'is surely more of degree than of kind': after all, De Witt's proportions between the chances of dying in two age ranges are just a crude estimate that a mortality table will simply render more precise. The difference is in the very 
construction of the estimate: whereas De Witt arrives at his proportions building on the agreement between the contracting parties alones, Halley arrives at his chances of death from empirical frequencies. In negotiating a fair price, De Witt's contracting parties are free to agree on whatever proportion they think fit, according to their own preferences (e.g., risk aversion). If those same parties were to negotiate a fair price with Halley's mortality tables, their estimates of the chances of dying would be empirically constrained. Ideally the mortality table should capture the objective chance of dying, but the hope of constructing this table, as we will see next, was soon frustrated.

13. This is, of course, our own interpretation. A reviewer suggests that the increasing deployment of an actuarial apparatus served in large measure as a rhetorical device to make financial establishments appear more solid and scientific. Both interpretations are not contradictory though. The use of actuarial mathematics surely persuaded many to buy insurance, but we are just focusing here on the concepts at play in the litigants' arguments on the fairness of the Calenberg contract. The terms of the debate reveal traces of the two views of justice we have discussed, not unexpectedly since both of them emerge from the legal debate on aleatory contracts.

14. As life annuities were sold at a constant price irrespective of life expectancy, the expected return of buying a life annuity is the rise in life expectancy, which is maximal around six years.

15. By way of illustration, we can compare our table 2 with the tables British companies use in the 19th century according to (Alborn, 2009: 107). If we focus on life expectancy at 20 , in the 18th century individuals of this age could expect to live, on average, 31,9 years more, with a standard deviation of 5.2. In the 19th 
century, the average was 40,6 years, and the standard deviation 2,7 . If we exclude the only $18^{\text {th }}$ century table in (ibid.), the figures are, respectively, 41.4 and 0,98 . The increase in the former can be interpreted as a rise in longevity. The decrease in the latter suggests that indeed the tables in use during the 19th were more convergent than in the previous century. NB: since some of the tables differentiate between men and women, we mix them assuming that each of the groups amounts to $50 \%$ of the population.

16. Finlaison actually followed principles already implemented by Struyck (gender classification) and Duvillard de Durand (population growth) and constructed his table drawing on data from buyers of life annuities issued in the previous years (Turnbull, 2016: 75-ff).

17. The contract was considered invalid if placed on the life 'of a person attacked by a disorder of which he died within twenty days from the date of the contract' (art. 1975).

\section{Author biographies}

Antonio J. Heras is professor of actuarial science at Universidad Complutense de Madrid. He has published in the main journals in the field.

Pierre-Charles Pradier is associate professor of economics at Paris 1 Panthéon-Sorbonne University. He has been the dean of the Faculty of economics, before serving as viceprovost, then dean of the national school of insurance (ENAss/CNAM). He has authored numerous papers on the economics of risk and insurance, in a historical perspective, as well as financial regulation. Latest book published: Financial Regulation in the EU from Resilience to Growth (with Raphaël Douady and Clément Goulet, Palgrave Macmillan) 
David Teira teaches history and philosophy of science at UNED, the Spanish Open University. He has worked on the uses of statistics in economics and medicine. His webpage is: http://www.uned.es/personal/dteira 